\title{
The effects of different spices on chemical, biochemical, textural and sensory properties of White cheeses during ripening
}

\author{
Zekai Tarakçı*, Fahrettin Deveci \\ University of Ordu, Department of Food Engineering, Faculty of Agriculture, Turkey \\ ${ }^{*}$ Corresponding author: E-mail: zetarakci@hotmail.com
}

\section{Abstract}

The aim of this study was to test the effects of various spices on the physicochemical and sensory properties of white cheese. Six different white cheeses were produced by incorporating the spices of black cumin, mint, thyme, red pepper and isot pepper at a ratio of $3 \%(\mathrm{w} / \mathrm{v})$ of the cheese milk. All cheeses were vacuum-packed and ripened at $4 \pm 7^{\circ} \mathrm{C}$. On the $2^{\text {nd }}, 15^{\text {th }}, 30^{\text {th }}, 60^{\text {th }}$ and $90^{\text {th }}$ days of ripening, dry matter, fat, pH, titratable acidity, salt, total proteins, ripening index, non-protein nitrogen rate, amino nitrogen rate, electrophoretic casein fractions, textural and sensory properties were determined. Isot pepper and black cumin increased the proteolysis rates of white cheeses with higher degradation rates on $\beta$-casein fraction, indicating that these cheese samples had more pronounced ripening. On the other hand, thyme and isot pepper were more effective on $\mathrm{a}_{\mathrm{s} 1}$-casein fraction. All tested spices, except isot pepper, contributed to the sensory properties of white cheeses, by increasing the consumer acceptance. This study reveals spice addition had positive effects on chemical, biochemical and sensory characteristics of white cheese, and thus, white cheese with spice addition is an alternative novel product with a good potential.

Keywords: spice, white cheese, ripening, texture

\section{Introduction}

Spices are defined as edible substances obtained from dried, whole and/or crumbled seeds, fruits, flowers, bark, root, stem, tubers, leaves, stalks and onions of various plants. These edible compounds are generally used to give colour, taste, smell, and flavour to food products (TGK 2013). More recently, using spices and herbs to control microbial growth in processed dairy products has been a common practice. Cumin, thyme, mint, and fennel have been the centre of focus as natural antimicrobials. Their antimicrobial properties are mainly attributed to their chemical contents namely thymol, carvacrol, linalool, menthol, menthone, transanetole, estragol, p-cymene and the cumic aldehyde etc. (Singh et al., 2015; Akramiet al., 2015; Akarca et al., 2016).

In addition, spices generally make the presentation of food more appealing (Üner et al., 2000). In recent years, an increasing demand for natural and 
whole foods containing no additives has contributed the use of spices and extracts in food industry for conservation purposes (Coşkun 2010). Several research groups used spices in white cheese production as antimicrobial agents to increase its shelf life and to make the cheese more attractive. In addition, spice addition resulted in a reduction on the amount of salt used during cheese production, and thus, structural defects caused by salt were prevented (Ayar and Akyüz, 2003).

White cheese is the most commonly produced and consumed cheese type in Turkey. It is a pickled variety similar to Feta and Teleme cheeses produced in Greece and in the Middle East countries (Cinbas and Kilic, 2006). A mixture of Lactococcus (LC.) lactis ssp. lactis and Lc. lactis ssp. cremoris bacteria at different ratios are commonly used as the starter culture in the production of high quality-white cheeses having desirable taste and flavour (Dagdemir et al., 2003). Recently, there has been a growing interest in finding natural additives that can increase the shelf stability of dairy products as well as contribute to their taste and flavour properties. In this research, we aimed to investigate how different spices including black cumin, mint, thyme, red pepper and isot pepper affect the chemical, physicochemical, biochemical and sensory properties of white cheese.

\section{Materials and methods}

\section{Materials}

Cow milk was obtained from a local dairy plant in Ordu, Turkey. Choozit MA 16 (Danisco/DuPont) containing a mixture of Lc. lactis ssp. lactis and Lc. lactis ssp. cremoris was used as starter culture. Commercial rennet (1/16000) was obtained from Mayasan Company ${ }^{\oplus}$, Istanbul. All spices were products of Bağdat Baharat Company (Kahramanmaraş, Turkey) and purchased from local markets. In addition, food grade $\mathrm{CaCl}_{2}$ (Tekkim Chemicals, Bursa, Turkey) was used to maintain the calcium balance in the milk with a concentration of $0.02 \%(v / v)$.

\section{White cheese manufacture}

Raw milk was pasteurized at $85^{\circ} \mathrm{C}$ for $15 \mathrm{sec}-$ onds and cooled to $32{ }^{\circ} \mathrm{C}$. Starter culture was added at the level of $1 \%$ and held for 60 min. Then milk was coagulated with rennet for 75 min. After coagulation, curd was cut into 8-10 mm cubes with a wire knife and pressed for 120 min. Whole curd was divided into six portions one being the control group (CC) without any spice. Selected spices were added (3\% (w/v), based on milk volume) to the rest of the five groups as follows; black cumin (B1), mint (B2), thyme (B3), red pepper (B4) and isot pepper (B5). Curd was weighted and spices were thoroughly mixed into the curds. Curd was pressed overnight and then cut into blocks with dimensions of $6 \times 6 \times 5$ $\mathrm{cm}$ (Figure 1). The curds were salted with dry salt (the amount of dry salt used was $3 \%$ of cheese weight) and held $24 \mathrm{~h}$ within salt. The cheese samples were vacuum-packed and ripened at $4 \pm 1{ }^{\circ} \mathrm{C}$ for 90 days. Two batches of cheese samples were prepared for each cheese type.

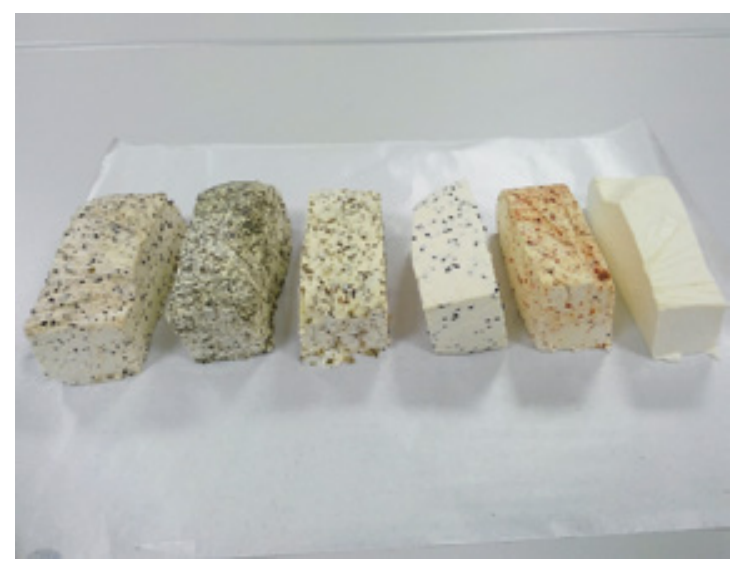

FIGURE 1. Cheeses with added spices: black cumin, mint, thyme, isot pepper, red pepper and plain

\section{Chemical analysis}

Dry matter content was determined in a laboratory oven at $105^{\circ} \mathrm{C}$ until a constant weight was obtained. Total nitrogen concentration of samples was determined by micro-Kjeldahl procedure described by Case et al. (1985) with a micro-Kjeldahl analyzer UDK-149 (VELP Scientifica, Usmate, Italy) and calculated by the following formula; Total $\mathrm{N} \%$ $=$ normality of acid used in the titration $\mathrm{x}$ volume of acid used in the titration $(\mathrm{mL}) \times 0.014 \times 100 /$ 
sample weight (g). Total protein was calculated by multiplying $\%$ total nitrogen with the factor of 6.38. Fat content was measured by the Van-Gulik method (IDF, 1986). Salt content was determined according to the Mohr method (Nielsen, 2003), $\mathrm{pH}$ was determined with a digital $\mathrm{pH}$ meter (Starter 3100, USA) described by Case et al. (1985). All analyses were performed in duplicate.

\section{Proteolysis analysis}

Water-soluble nitrogen (WSN), trichloroacetic acid-soluble nitrogen (TCA-SN), and phosphotungstic acid-soluble nitrogen (PTA-SN) were determined according to the method described by Kamaly et al. (1989) and Butikofer et al. (1993).

\section{Urea-PAGE electrophoresis}

The electrophoretic analysis of protein patterns was conducted as previously described by Creamer (1991) with some modifications made by Çelik and Tarakçı (2017).

\section{Colour analyses}

Colour measurements were performed using a colorimeter (Minolta Chroma Meter, CR-400, Osaka, Japan). The $L^{*}, a^{*}$ and $b^{*}$ colour measurements were determined according to the CIE Lab colour space system. Three readings were taken for each sample and arithmetic means were calculated.

\section{Texture profile analyses}

For the texture analysis, the temperature of the cheeses was adjusted to $20 \pm 2{ }^{\circ} \mathrm{C}$. The cheeses were cut into cubes with dimensions of $20 \times 20 \times 20$ $\mathrm{mm}$ with a cutting wire. Texture profile analyses (hardness, springiness, gumminess, cohesiveness, adhesiveness, resilience and chewiness) of cheese samples were performed using TA-XT2 (Stable Micro Systems Ltd., Surrey, UK). Analysis conditions: P/36 aluminium cylinder probe $(36 \mathrm{~mm}$ diameter, AACC) and cell strength $25 \mathrm{~kg}$ weight, test speed $0.4 \mathrm{~mm} / \mathrm{s}$, initial test speed $1.0 \mathrm{~mm} / \mathrm{sec}$, print $40 \%$, hold time 5 sec. (Everard et al., 2006).

\section{Sensory analysis}

Sensory assessments of White cheeses were carried out by a six-member panel consisting of the university staff based on their experience in sensory evaluation of White cheeses. Prior to assessment, each cheese was cut into $10 \mathrm{~g}$ cubes, equilibrated to room temperature $\left(20^{\circ} \mathrm{C}\right)$ by laying for 4 $\mathrm{h}$ at room temperature and served to the panelists randomly. The overall sensory quality was assessed using a hedonic scaling method (1-10 points), where 1 is unacceptable and 10 is very good for appearance and colour, body and texture, flavour and overall acceptability. Panelists were also instructed to report any defects in colour and appearance (wet, dry, cracks), texture (hard, soft, pasty, crumbly, grainy), odour, flavour (rancid, salty, bitter, sour) and overall acceptability as well. Water was provided for mouth rinsing between evaluations of the sample.

\section{Statistical analysis}

All the analyses were performed in duplicate. All statistical calculations were performed using Statistical Software (SPSS 2000), and the obtained values are presented as mean \pm standard deviation. Variance analysis (ANOVA) was performed for the determination of statistical differences between mean values for cheese types and ripening periods; then, differences found statistically significant were compared using Duncan's multiple range test. The significance levels of $\mathrm{P}<0.05$ was used for statistical differences.

\section{Results and discussion}

\section{Chemical changes in white cheeses}

The dry matter content in cheese varies depending on the characteristics of the process parameters, the type of cheese, and the degree of cheese ripening. Throughout 90 days of ripening, dry matter, fat and salt contents increased significantly $(\mathrm{P}<0.05)$ for all types of cheeses, possibly because of salt diffusion into the cheese (Tarakçi and Tunçtürk, 2008) and concomitant syneresis. As shown in Table 1, there is a significant difference in dry matter ratio between cheese varieties 
$(\mathrm{P}<0.05)$. Interaction between cheese type and ripening period is also important at $\mathrm{P}<0.05$ level. Whey drainage was increased with added spices and lead to higher dry matter content in these cheeses compared to the control cheese.

TABLE 1. Changes in dry matter, fat, protein and pH values of cheese samples during ripening*

\begin{tabular}{|c|c|c|c|c|c|c|c|}
\hline & \multirow{2}{*}{$\begin{array}{l}\text { Cheese } \\
\text { Types }\end{array}$} & \multicolumn{6}{|c|}{ Ripening time (days) } \\
\hline & & 2 & 15 & 30 & 60 & 90 & $\overline{\mathrm{X}}$ \\
\hline \multirow{7}{*}{$\begin{array}{l}\text { Dry } \\
\text { matter } \\
(\%)\end{array}$} & $\mathrm{CC}$ & $47.64 \pm 0.51$ & $44.19 \pm 0.19$ & $43.99 \pm 0.20$ & $44.48 \pm 0.33$ & $43.55 \pm 0.25$ & $44.77 \pm 1.50^{\text {aa }}$ \\
\hline & B1 & $48.61 \pm 0.23$ & $46.10 \pm 0.18$ & $46.61 \pm 0.11$ & $47.73 \pm 0.25$ & $46.36 \pm 0.17$ & $47.37 \pm 0.83^{b c}$ \\
\hline & B2 & $48.53 \pm 0.49$ & $51.13 \pm 2.71$ & $47.98 \pm 0.21$ & $49.40 \pm 0.06$ & $46.80 \pm 0.09$ & $48.77 \pm 1.91^{d}$ \\
\hline & B3 & $48.95 \pm 1.49$ & $49.02 \pm 0.30$ & $45.99 \pm 0.84$ & $48.44 \pm 0.35$ & $49.07 \pm 0.10$ & $48.47 \pm 1.54^{\text {cd }}$ \\
\hline & B4 & $46.91 \pm 0.41$ & $46.09 \pm 0.10$ & $45.58 \pm 0.16$ & $48.03 \pm 0.21$ & $46.39 \pm 0.05$ & $46.63 \pm 0.85^{b}$ \\
\hline & B5 & $47.38 \pm 0.78$ & $47.59 \pm 1.39$ & $44.65 \pm 0.10$ & $47.08 \pm 0.46$ & $46.09 \pm 0.19$ & $46.56 \pm 1.32^{b}$ \\
\hline & $\bar{x}$ & $48.00 \pm 1.06^{a}$ & $47.76 \pm 2.60^{\mathrm{a}}$ & $45.80 \pm 1.35^{\mathrm{ab}}$ & $47.52 \pm 1.56^{\mathrm{bc}}$ & $46.38 \pm 1.62^{c}$ & \\
\hline \multirow[t]{7}{*}{ Fat (\%) } & CC & $18.75 \pm 0.25$ & $20.00 \pm 0.50$ & $19.25 \pm 0.25$ & $20.75 \pm 0.25$ & $20.25 \pm 0.25$ & $19.80 \pm 0.78^{a}$ \\
\hline & B1 & $21.50 \pm 1.50$ & $21.50 \pm 0.50$ & $22.00 \pm 0.50$ & $21.50 \pm 0.50$ & $22.25 \pm 0.75$ & $21.75 \pm 0.90^{b}$ \\
\hline & B2 & $21.50 \pm 0.50$ & $25.50 \pm 0.50$ & $23.50 \pm 0.50$ & $23.25 \pm 0.25$ & $22.25 \pm 0.25$ & $23.20 \pm 1.42^{c}$ \\
\hline & B3 & $21.75 \pm 0.25$ & $23.25 \pm 0.25$ & $22.50 \pm 0.50$ & $22.00 \pm 0.01$ & $22.75 \pm 0.25$ & $22.45 \pm 0.61^{b c}$ \\
\hline & B4 & $22.00 \pm 0.01$ & $21.25 \pm 0.25$ & $22.50 \pm 0.50$ & $23.50 \pm 0.01$ & $22.25 \pm 1.25$ & $22.30 \pm 0.95^{b c}$ \\
\hline & B5 & $22.50 \pm 0.50$ & $21.75 \pm 0.25$ & $21.00 \pm 1.00$ & $23.25 \pm 0.25$ & $21.75 \pm 0.25$ & $22.05 \pm 0.93^{b}$ \\
\hline & $\bar{x}$ & $21.33 \pm 1.39^{a}$ & $22.21 \pm 1.80^{\mathrm{ab}}$ & $21.79 \pm 1.48^{\mathrm{ab}}$ & $22.38 \pm 1.06^{b}$ & $21.92 \pm 1.02^{\mathrm{ab}}$ & \\
\hline \multirow{7}{*}{$\begin{array}{l}\text { Protein } \\
(\%)\end{array}$} & CC & $17.98 \pm 0.34$ & $18.43 \pm 0.56$ & $16.76 \pm 0.11$ & $16.93 \pm 0.90$ & $16.43 \pm 0.01$ & $17.31 \pm 0.91^{a}$ \\
\hline & B1 & $21.90 \pm 1.34$ & $18.20 \pm 0.11$ & $19.90 \pm 0.34$ & $18.84 \pm 0.11$ & $18.58 \pm 0.83$ & $19.48 \pm 1.52^{\mathrm{bc}}$ \\
\hline & B2 & $22.57 \pm 0.22$ & $19.88 \pm 1.57$ & $19.22 \pm 0.56$ & $19.96 \pm 0.34$ & $18.83 \pm 0.25$ & $20.09 \pm 1.52^{c}$ \\
\hline & B3 & $21.45 \pm 1.34$ & $20.11 \pm 0.45$ & $20.57 \pm 0.11$ & $19.85 \pm 0.45$ & $20.48 \pm 0.41$ & $20.49 \pm 0.88^{c}$ \\
\hline & B4 & $19.77 \pm 0.56$ & $18.20 \pm 0.56$ & $18.33 \pm 0.56$ & $19.40 \pm 0.22$ & $18.08 \pm 0.01$ & $18.76 \pm 0.82^{b}$ \\
\hline & B5 & $20.56 \pm 0.01$ & $18.43 \pm 0.78$ & $19.00 \pm 0.56$ & $18.39 \pm 0.34$ & $17.92 \pm 0.17$ & $18.86 \pm 1.03^{b}$ \\
\hline & $\bar{x}$ & $20.71 \pm 1.73^{a}$ & $18.87 \pm 1.14^{b}$ & $18.96 \pm 1.28^{b}$ & $18.89 \pm 1.13^{b}$ & $18.39 \pm 1.27^{b}$ & \\
\hline \multirow[t]{7}{*}{$\mathrm{pH}$} & CC & $4.60 \pm 0.02$ & $4.83 \pm 0.01$ & $4.65 \pm 0.01$ & $4.68 \pm 0.01$ & $4.67 \pm 0.03$ & $4.68 \pm 0.08^{a}$ \\
\hline & B1 & $4.81 \pm 0.02$ & $4.81 \pm 0.01$ & $4.77 \pm 0.02$ & $4.80 \pm 0.01$ & $4.70 \pm 0.01$ & $4.77 \pm 0.04^{e}$ \\
\hline & B2 & $4.65 \pm 0.01$ & $4.90 \pm 0.01$ & $4.69 \pm 0.01$ & $4.68 \pm 0.02$ & $4.54 \pm 0.01$ & $4.69 \pm 0.12^{\mathrm{ab}}$ \\
\hline & B3 & $4.81 \pm 0.01$ & $4.83 \pm 0.01$ & $4.74 \pm 0.01$ & $4.72 \pm 0.02$ & $4.66 \pm 0.01$ & $4.75 \pm 0.06^{\text {de }}$ \\
\hline & B4 & $4.76 \pm 0.01$ & $4.86 \pm 0.01$ & $4.67 \pm 0.01$ & $4.76 \pm 0.01$ & $4.55 \pm 0.01$ & $4.72 \pm 0.11^{b c}$ \\
\hline & B5 & $4.83 \pm 0.01$ & $4.89 \pm 0.01$ & $4.67 \pm 0.01$ & $4.71 \pm 0.04$ & $4.64 \pm 0.06$ & $4.74 \pm 0.10^{\text {cd }}$ \\
\hline & $\bar{x}$ & $4.74 \pm 0.09^{b}$ & $4.85 \pm 0.03^{a}$ & $4.69 \pm 0.04^{c}$ & $4.72 \pm 0.05^{c}$ & $4.62 \pm 0.06^{d}$ & \\
\hline \multirow[t]{7}{*}{ Salt (\%) } & CC & $2.52 \pm 0.06$ & $2.40 \pm 0.06$ & $2.90 \pm 0.09$ & $3.13 \pm 0.03$ & $2.95 \pm 0.09$ & $2.78 \pm 0.28^{\mathrm{ab}}$ \\
\hline & B1 & $2.52 \pm 0.06$ & $2.05 \pm 0.06$ & $2.78 \pm 0.03$ & $2.69 \pm 0.01$ & $2.87 \pm 0.06$ & $2.58 \pm 0.29^{c d}$ \\
\hline & B2 & $2.40 \pm 0.06$ & $2.98 \pm 0.06$ & $2.93 \pm 0.12$ & $2.52 \pm 0.06$ & $2.57 \pm 0.01$ & $2.68 \pm 0.24^{b c}$ \\
\hline & B3 & $2.34 \pm 0.01$ & $2.63 \pm 0.06$ & $2.57 \pm 0.01$ & $2.60 \pm 0.03$ & $2.54 \pm 0.03$ & $2.54 \pm 0.11^{d}$ \\
\hline & B4 & $2.40 \pm 0.06$ & $2.34 \pm 0.01$ & $2.72 \pm 0.03$ & $3.04 \pm 0.01$ & $2.98 \pm 0.06$ & $2.70 \pm 0.29^{\mathrm{ab}}$ \\
\hline & B5 & $2.93 \pm 0.12$ & $2.52 \pm 0.06$ & $2.60 \pm 0.03$ & $3.10 \pm 0.06$ & $2.81 \pm 0.01$ & $2.79 \pm 0.22^{a}$ \\
\hline & $\bar{x}$ & $2.52 \pm 0.21^{\mathrm{a}}$ & $2.49 \pm 0.29^{a}$ & $2.75 \pm 0.15^{b}$ & $2.85 \pm 0.25^{c}$ & $2.79 \pm 0.18^{c}$ & \\
\hline
\end{tabular}

*Values are means of two replicated trials \pm standard deviation; different superscript lowercase letters indicate significant difference between cheese types and ripening time $(\mathrm{P} \leq 0.05)$

The ratio of fat among the cheeses was found to be the lowest with $19.8 \%$ in the control samples and highest with $23.2 \%$ in the pepper-enriched cheeses. There was no steady increase or decrease in fat rate during ripening with an overall mean of
$21.93 \pm 1.43 \%$. Significant differences were found among the cheese varieties in terms of protein ratios. The highest value in terms of salt amount was recorded on the $60^{\text {th }}$ day of ripening and the lowest on the $15^{\text {th }}$ day, and this difference was statisti- 
cally significant. The highest salt content (2.79\%) was found in isot pepper cheese samples, and the lowest (2.54\%) was found in thyme-added samples and the difference was statistically significant (Table 1). The dry matter and salt contents showed fluctuations during the ripening period, probably as an integrated consequence of dry salting and vacuum packaging. The dry matters increased due to intense salt penetration and whey drainage in the first fifteen days. However, release of whey was not possible due to the vacuum packaging and there were probably releases and intakes of whey that lead to fluctuations in dry matter contents. This condition also affected the protein contents similarly.

The highest $\mathrm{pH}$ value $(4.77 \pm 0.04)$ was determined in $\mathrm{B} 1$ samples and the lowest $(4.68 \pm 0.08)$ in control cheeses (K). The $\mathrm{pH}$ values of minty cheese samples (B2) were statistically similar to the control cheese samples. The highest mean $\mathrm{pH}$ values of cheese samples during ripening were $4.85 \pm 0.03$ after 15 days, and the lowest values were $4.62 \pm 0.06$ after 90 days. The overall average $\mathrm{pH}$ value was calculated as $4.73 \pm 0.09$. These values were lower than the $\mathrm{pH}$ values reported by Peralta (1986) in pineapple queso de pina cheeses, and the white soft cheeses in the studies by Dimitreli et al. (2017). On the other hand, it was higher than the $\mathrm{pH}$ values determined by Topçu and Saldamlı (2006) and Soltani et al. (2015) in Turkish and Iranian white cheeses, respectively.

\section{Changes in nitrogen fractions of cheese}

Proteolysis is the most complex and the primary biochemical event that occurs during ripening in most cheese varieties, including white cheese. An increase in the concentrations of proteolysis products such as peptides and amino acids is an indicator of ripening in cheese. Variations in the nitrogen fractions of the cheeses after 2, 30, 60, and 90 days of ripening are given in Table 2 . There is a continuous increase of nitrogen fractions during ripening. Statistically significant differences were found in terms of the degree of ripening among the cheese varieties. The increase in ripening rate was initially achieved with the aid of microbial enzymes in addition to the enzymatic activity (Kaminarides et al., 1990). The increase in parameters of proteolysis during cheese ripening is closely related to the increase in bacterial activity and enzyme activity over time. Several authors have found that advancing the ripening time increases the ripening values and leads to an increase in protein degradation in white cheeses (Dagdemir et al., 2003; Hayaloglu et al., 2004; Goncu and Alpkent, 2005). The non-protein nitrogen (NPN) is comprised of amino acids and medium and short chain peptides. The dry matter and protein concentrations together with the $\mathrm{pH}$ values are effective on the NPN ratios of cheese samples (Fritsch et al., 1992). The highest NPN ratio was recorded in the B3 cheese samples, followed by B2 cheese samples and then B4 and B1 cheese samples, which were not statistically different among each other. The lowest NPN ratios were found in $\mathrm{B} 5$ and control cheese samples and there was no significant difference between them $(P<0.05)$. These values were higher than those obtained by Topçu and Saldamlı (2006) in white cheeses and by Agboola and Radovanovic-Tesic (2002) in Australian herb cheeses, while the values obtained by Hayaloğlu and Karabulut (2013) and Tunçtürk et al. (2014) were found to be lower than herby cheese. Dimitreli et al. (2017) found similar NPN values in herby cheeses.

Protease petone nitrogen (PPN) is comprised of peptides and amino acids with less than 600 daltons in molecular weight and those are soluble in $5 \%$ phosphotungstic acid (PTA) (Hannon et al., 2003). It is believed that the level of free amino acids and peptides soluble in $5 \%$ PTA was a reliable indicator of the level of cheese flavor development (McSweeney and Sousa, 2000) and this nitrogen fraction is closely related to peptidolytic activity of starter and non- starter microflora (Scolari et al.,1993). Table 2 shows that there was a continuous increase in the PPN ratio during ripening as well as in the nitrogen ratio, the ripening index and the NPN ratio. 
TABLE 2. Changes in the ripening index, TCA-SN/TN and PTA-SN/TN during ripening of cheese samples*

\begin{tabular}{|c|c|c|c|c|c|c|c|}
\hline & \multirow{2}{*}{$\begin{array}{l}\text { Cheese } \\
\text { Types }\end{array}$} & \multicolumn{6}{|c|}{ Ripening time (days) } \\
\hline & & 2 & 15 & 30 & 60 & 90 & $\bar{x}$ \\
\hline \multirow{7}{*}{$\begin{array}{l}\text { Ripening } \\
\text { index } \\
\text { (WSN/ } \\
\text { TN) (\%) }\end{array}$} & CC & $8.82 \pm 0.33$ & $9.89 \pm 0.11$ & $11.91 \pm 0.02$ & $17.84 \pm 0.82$ & $24.65 \pm 0.79$ & $14.62 \pm 5.93^{a}$ \\
\hline & B1 & $7.46 \pm 0.50$ & $10.04 \pm 0.34$ & $12.68 \pm 0.12$ & $16.57 \pm 0.13$ & $21.83 \pm 0.74$ & $13.72 \pm 5.07^{\mathrm{bc}}$ \\
\hline & B2 & $8.00 \pm 0.67$ & $10.23 \pm 0.56$ & $12.96 \pm 0.30$ & $16.51 \pm 0.16$ & $24.96 \pm 0.59$ & $14.53 \pm 5.96^{\mathrm{ab}}$ \\
\hline & B3 & $8.45 \pm 0.48$ & $9.29 \pm 0.66$ & $13.32 \pm 0.39$ & $18.78 \pm 0.23$ & $25.62 \pm 0.83$ & $15.09 \pm 5.96^{a}$ \\
\hline & B4 & $8.05 \pm 0.36$ & $9.88 \pm 0.33$ & $13.58 \pm 0.31$ & $16.99 \pm 0.20$ & $24.56 \pm 0.48$ & $14.61 \pm 5.86^{\mathrm{ab}}$ \\
\hline & B5 & $7.63 \pm 0.05$ & $10.31 \pm 0.75$ & $12.29 \pm 0.11$ & $14.86 \pm 0.27$ & $22.00 \pm 0.32$ & $13.42 \pm 4.92^{c}$ \\
\hline & $\bar{x}$ & $8.07 \pm 0.46^{a}$ & $9.94 \pm 0.61^{b}$ & $12.79 \pm 0.62^{c}$ & $16.92 \pm 1.27^{d}$ & $23.94 \pm 1.61^{e}$ & \\
\hline \multirow{7}{*}{$\begin{array}{l}\text { TCA-SN/ } \\
\text { TN (\%) }\end{array}$} & CC & $3.40 \pm 0.41$ & $4.01 \pm 0.23$ & $4.94 \pm 0.02$ & $5.40 \pm 0.12$ & $7.88 \pm 0.16$ & $5.13 \pm 1.56^{\mathrm{ab}}$ \\
\hline & B1 & $3.15 \pm 0.15$ & $3.94 \pm 0.08$ & $4.87 \pm 0.01$ & $4.97 \pm 0.05$ & $9.12 \pm 0.27$ & $5.21 \pm 2.07^{b}$ \\
\hline & B2 & $3.26 \pm 0.01$ & $4.33 \pm 0.24$ & $5.57 \pm 0.28$ & $6.13 \pm 0.15$ & $10.73 \pm 0.10$ & $6.00 \pm 2.57 c$ \\
\hline & B3 & $3.64 \pm 0.32$ & $4.07 \pm 0.29$ & $6.75 \pm 0.03$ & $7.12 \pm 0.11$ & $11.05 \pm 0.35$ & $6.53 \pm 2.67^{d}$ \\
\hline & B4 & $3.83 \pm 0.06$ & $4.15 \pm 0.20$ & $6.05 \pm 0.43$ & $5.51 \pm 0.06$ & $7.35 \pm 0.14$ & $5.38 \pm 1.31^{b}$ \\
\hline & B5 & $2.69 \pm 0.32$ & $3.24 \pm 0.08$ & $4.39 \pm 0.20$ & $5.17 \pm 0.04$ & $8.24 \pm 0.17$ & $4.75 \pm 1.96^{a}$ \\
\hline & $\bar{x}$ & $3.33 \pm 0.45^{\mathrm{a}}$ & $3.95 \pm 0.40^{b}$ & $5.43 \pm 0.82^{c}$ & $5.72 \pm 0.73^{c}$ & $9.06 \pm 1.42^{d}$ & \\
\hline \multirow{7}{*}{$\begin{array}{l}\text { PTA-SN/ } \\
\text { TN (\%) }\end{array}$} & $\mathrm{CC}$ & $0.68 \pm 0.01$ & $0.95 \pm 0.27$ & $1.07 \pm 0.12$ & $1.66 \pm 0.12$ & $1.89 \pm 0.11$ & $1.25 \pm 0.48^{\mathrm{a}}$ \\
\hline & B1 & $0.82 \pm 0.05$ & $0.93 \pm 0.06$ & $1.02 \pm 0.01$ & $1.31 \pm 0.04$ & $1.68 \pm 0.07$ & $1.15 \pm 0.31^{\mathrm{a}}$ \\
\hline & B2 & $0.61 \pm 0.26$ & $1.19 \pm 0.17$ & $1.62 \pm 0.15$ & $2.30 \pm 0.06$ & $2.66 \pm 0.04$ & $1.68 \pm 0.75^{b}$ \\
\hline & B3 & $1.29 \pm 0.06$ & $1.36 \pm 0.01$ & $2.04 \pm 0.03$ & $2.34 \pm 0.05$ & $2.61 \pm 0.05$ & $1.93 \pm 0.53^{c}$ \\
\hline & B4 & $0.52 \pm 0.34$ & $0.60 \pm 0.04$ & $1.41 \pm 0.02$ & $1.74 \pm 0.04$ & $2.05 \pm 0.05$ & $1.27 \pm 0.63^{a}$ \\
\hline & B5 & $0.48 \pm 0.10$ & $0.66 \pm 0.07$ & $1.02 \pm 0.05$ & $1.42 \pm 0.05$ & $1.69 \pm 0.06$ & $1.05 \pm 0.46^{a}$ \\
\hline & $\bar{x}$ & $0.74 \pm 0.33^{a}$ & $0.95 \pm 0.30^{b}$ & $1.36 \pm 0.38^{c}$ & $1.79 \pm 0.40^{d}$ & $2.10 \pm 0.41^{e}$ & \\
\hline
\end{tabular}

*Values are means of two replicated trials \pm standard deviation; different superscript lowercase letters indicate significant difference between cheese types and ripening time $(P \leq 0.05)$

\section{Assessment of proteolysis}

Figure 2 shows the urea-PAGE electrophoretogram for the casein fractions of $a_{s 1}{ }^{-}, a_{s 2}-, \beta-, a_{1}-1$ peptide and other breakdown products of White cheeses with different types of spices during ripening. During the ripening period, the amounts of a- and $\beta$-caseins of all cheese samples were decreased. However, the amounts of $\mathrm{as}_{1}-\mathrm{l}$ peptide, $\gamma$-casein and other metabolites were increased.

Proteolysis of $\mathrm{a}_{\mathrm{s} 1}$-casein follows a three-step pattern (Fox 1989). Initially, the $a_{s 1}$-casein is cleaved from the Phe23-Phe24 linkages into $a_{s 1}$-casein ( $f 1$ 23) and $a_{s 1}$-casein (f24-199). Secondly, $a_{s 1}$-casein (f24-199) is hydrolysed to medium and small sized peptides by the coagulant enzyme, the indigenous enzymes and the bacterial enzymes and finally, bacterial enzymes break down small peptides into amino acids (Dave et al., 2003). $a_{s 1}$-casein was continuously degraded during the ripening period. The highest decrease in the amount of $\mathrm{a}_{\mathrm{S} 1}$-casein was found in the thyme and isot pepper-added cheese samples. Tarakçı et al. (2004), Hayaloğlu and Karabulut (2013), Tunçtürk et al. (2014) and Dimitreli et al. (2017) also found a decrease in the amount of $\mathrm{a}_{\mathrm{s} 1}$-casein in herby cheese during ripening. Furthermore, during the ripening period, the decrease in the amount of $\mathrm{a}_{\mathrm{s} 1}$-casein seems 

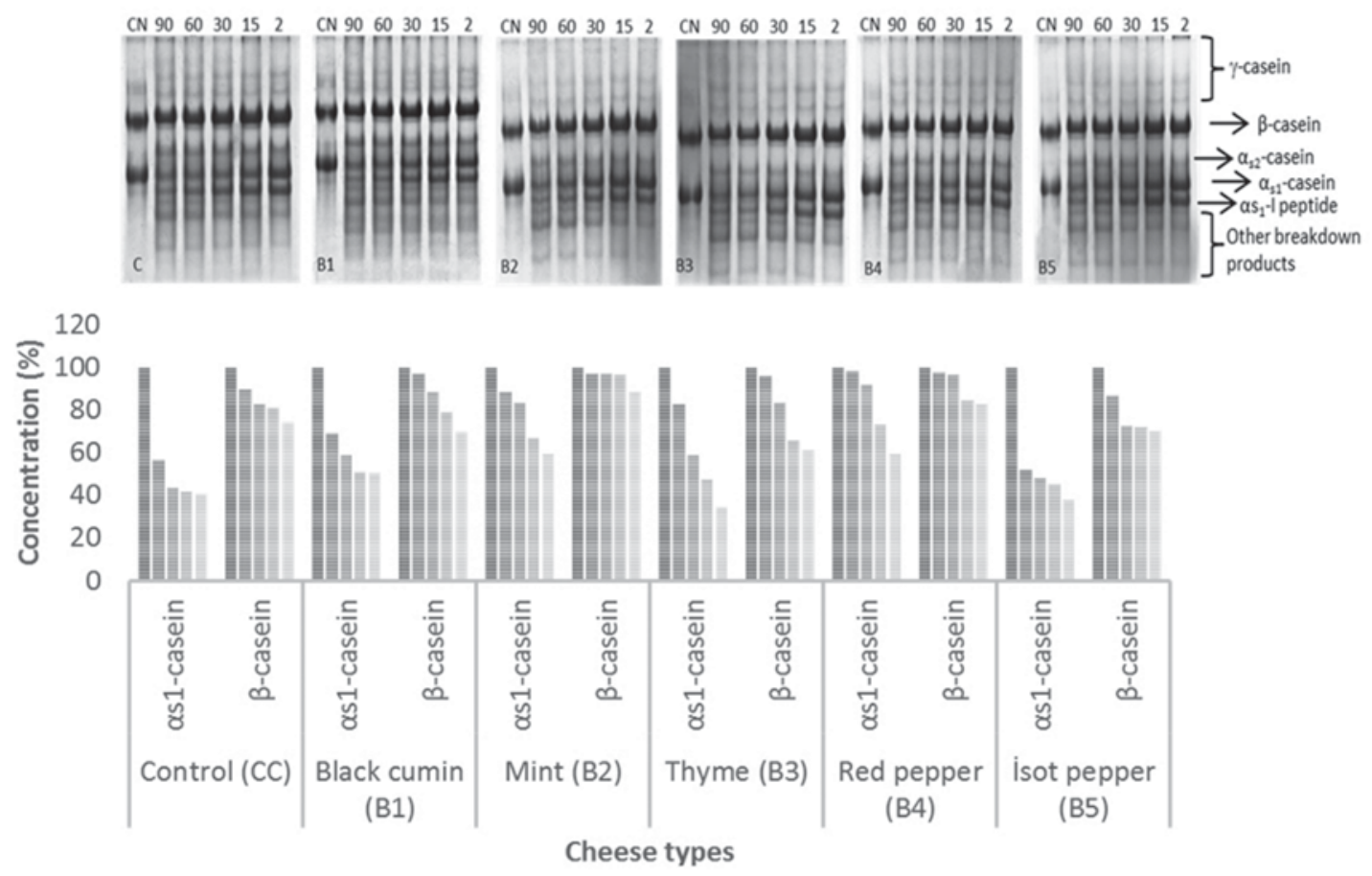

to be greater than the decrease in the amount of $\beta$-casein. However, the decrease in the amount of $\mathrm{a}_{\mathrm{s} 1}$-casein in mint, red pepper and cumin-added cheese was lower than the decline in the control group cheese. Considering starters' contribution to the proteolysis of $\mathrm{a}_{\mathrm{s} 1}$-casein it would be plausible to say that the antimicrobial activities of tested spices inhibited the microbial protease activities. However, a more comprehensive study is required to understand the whole mechanism.

The amount of $\mathrm{a}_{\mathrm{s} 2}$-casein determined in cheese samples also decreased during ripening. It has been reported that $\mathrm{a}_{\mathrm{s} 2}$-casein hydrolysis in cheese was also related to the activity of plasmin, the natural milk proteinase (Tarakçı and Tunçtürk, 2008).

The highest decrease in the amount of $\beta$-casein was observed in the thyme-added cheese, followed by the black cumin and isot pepper pepper-added cheeses. The least decrease in the amount of $\beta$-casein occurred in mint and red pepper-added cheeses. The amount of $\beta$-casein in the control group cheese was lower than that of mint and red pepper-added cheese; thyme, cucumber and isot pepper-added cheese. Many researches have reported that $\beta$-casein decreased during cheese ripening (Kim et al., 2004). $\gamma$-casein is a breakdown product of $\beta$-casein. Therefore, the amount of $\gamma$-casein increased in cheese samples during ripening. It has also been observed in other studies that the amount of $\mathrm{y}$-casein increased during ripening (Taivosalo et al., 2018).

The $\mathrm{as}_{1}-\mathrm{I}$ peptide is a large molecule peptide formed by hydrolysis of 24/25 peptide bond within the $a_{s 1}$-casein. The formation of $a_{s 1}-1$ peptide is largely catalysed by rennin (Grappin et al., 1985). From the second day of ripening all the cheeses were observed to have $a_{\mathrm{s} 1}{ }^{-1}$ peptides. At the beginning of the ripening period the amount of $\mathrm{a}_{\mathrm{S} 1}-\mathrm{I}$ peptide increased due to the effect of rennin and decreased in later periods. The obtained result is similar to the results obtained by Ceruti et al. (2016).

\section{Color changes in white cheese}

$L$, $a$, and $b$ values are given by a three-dimensional coordinate system in which the $L^{*}$ value indicates brightness (100) and darkness (0), a*indicates redness/greenness (+/-) and b* indicates yellow/ blue (+/-) (Jha, 2010). The $L$ value was found to be high in the control group cheese samples compared 
to the spice-added cheese samples and it was close to the full score value. The highest $L$ value was $96.18 \pm 2.84$ in the control group, as expected. The highest decrease in $L$ value was found in the cheese samples with thyme, isot pepper and mint in the order of $79.69 \pm 4.65,80.89 \pm 4.78,82.10 \pm 6.43$ (Table 3). It is thought that thyme and mint crumbles are light and have more scattering property in cheese, whereas isot pepper is thought to decrease $L$ value due to its coloring property.

TABLE 3. Changes in colour $L$, $a$ and $b$ values of cheese samples*

\begin{tabular}{|c|c|c|c|c|c|c|c|}
\hline & Cheese & Ripening tin & days) & & & & \\
\hline & Types & 2 & 15 & 30 & 60 & 90 & $\bar{x}$ \\
\hline L & CC & $98.80 \pm 0.84$ & $98.15 \pm 0.73$ & $98.29 \pm 0.45$ & $92.09 \pm 0.27$ & $93.58 \pm 0.26$ & $96.18 \pm 2.84^{a}$ \\
\hline & B1 & $92.83 \pm 1.00$ & $93.12 \pm 0.92$ & $90.23 \pm 1.94$ & $73.57 \pm 1.02$ & $88.25 \pm 0.97$ & $87.60 \pm 7.34^{b}$ \\
\hline & B2 & $83.54 \pm 0.55$ & $83.72 \pm 0.69$ & $83.05 \pm 0.94$ & $73.45 \pm 0.26$ & $74.71 \pm 0.47$ & $79.69 \pm 4.65^{c}$ \\
\hline & B3 & $88.65 \pm 2.01$ & $87.81 \pm 2.29$ & $83.90 \pm 0.17$ & $71.96 \pm 0.65$ & $78.20 \pm 0.32$ & $82.10 \pm 6.43^{d}$ \\
\hline & B4 & $89.31 \pm 1.11$ & $90.54 \pm 0.11$ & $87.96 \pm 0.82$ & $82.24 \pm 1.28$ & $84.02 \pm 0.53$ & $86.81 \pm 3.29^{b}$ \\
\hline & B5 & $85.17 \pm 1.59$ & $84.43 \pm 2.16$ & $82.73 \pm 1.81$ & $72.81 \pm 0.96$ & $79.31 \pm 0.89$ & $80.89 \pm 4.78^{d}$ \\
\hline & $\bar{X}$ & $89.72 \pm 5.20^{a}$ & $89.63 \pm 5.21^{a}$ & $87.69 \pm 5.60^{b}$ & $77.69 \pm 7.35^{d}$ & $83.01 \pm 6.43^{c}$ & \\
\hline a & CC & $1.54 \pm 0.04$ & $1.16 \pm 0.15$ & $1.28 \pm 0.20$ & $2.39 \pm 0.26$ & $1.79 \pm 0.04$ & $1.63 \pm 0.47^{b}$ \\
\hline & B1 & $0.63 \pm 0.08$ & $0.60 \pm 0.29$ & $0.86 \pm 0.32$ & $1.60 \pm 0.04$ & $1.95 \pm 0.09$ & $1.13 \pm 0.58^{b}$ \\
\hline & B2 & $0.32 \pm 0.45$ & $0.25 \pm 0.15$ & $0.10 \pm 0.64$ & $0.50 \pm 0.39$ & $0.63 \pm 0.22$ & $0.36 \pm 0.45^{\mathrm{a}}$ \\
\hline & B3 & $1.89 \pm 0.21$ & $0.74 \pm 0.31$ & $1.41 \pm 0.57$ & $1.71 \pm 0.26$ & $2.33 \pm 0.45$ & $1.62 \pm 0.65^{b}$ \\
\hline & B4 & $6.84 \pm 0.26$ & $7.20 \pm 0.71$ & $8.83 \pm 0.52$ & $9.58 \pm 1.04$ & $7.64 \pm 0.47$ & $8.02 \pm 1.22^{c}$ \\
\hline & B5 & $4.86 \pm 0.52$ & $4.12 \pm 0.59$ & $4.45 \pm 0.21$ & $5.63 \pm 0.46$ & $3.98 \pm 0.36$ & $4.61 \pm 0.74^{d}$ \\
\hline & $\bar{x}$ & $2.68 \pm 2.39^{a b}$ & $2.35 \pm 2.56^{a}$ & $2.82 \pm 3.04^{b}$ & $3.57 \pm 3.17^{c}$ & $3.05 \pm 2.30^{b}$ & \\
\hline$b$ & CC & $11.09 \pm 1.30$ & $11.37 \pm 0.95$ & $13.05 \pm 1.90$ & $13.00 \pm 0.18$ & $12.73 \pm 0.50$ & $12.25 \pm 1.42^{\mathrm{a}}$ \\
\hline & B1 & $9.81 \pm 0.80$ & $9.89 \pm 1.59$ & $10.38 \pm 1.62$ & $11.24 \pm 1.95$ & $10.93 \pm 1.53$ & $10.45 \pm 1.64^{\mathrm{ab}}$ \\
\hline & B2 & $10.56 \pm 0.70$ & $9.55 \pm 0.46$ & $9.48 \pm 0.63$ & $15.31 \pm 0.27$ & $10.71 \pm 0.89$ & $11.12 \pm 2.24^{a}$ \\
\hline & B3 & $7.05 \pm 0.99$ & $10.03 \pm 0.32$ & $10.53 \pm 1.64$ & $16.49 \pm 1.70$ & $11.46 \pm 0.76$ & $11.11 \pm 3.29^{a b}$ \\
\hline & B4 & $18.12 \pm 0.27$ & $21.00 \pm 0.67$ & $19.50 \pm 1.84$ & $22.42 \pm 0.70$ & $20.57 \pm 0.79$ & $20.32 \pm 1.76^{c}$ \\
\hline & B5 & $12.20 \pm 1.97$ & $12.94 \pm 1.09$ & $10.51 \pm 0.53$ & $15.10 \pm 4.29$ & $13.34 \pm 0.55$ & $12.82 \pm 2.66^{b}$ \\
\hline & $\bar{x}$ & $11.47 \pm 3.55^{a}$ & $12.46 \pm 4.10^{\mathrm{ab}}$ & $12.24 \pm 3.73^{\mathrm{ab}}$ & $15.59 \pm 4.06^{c}$ & $13.29 \pm 3.51^{b}$ & \\
\hline
\end{tabular}

*Values are means of two replicated trials \pm standard deviation; different superscript lowercase letters indicate significant difference between cheese types and ripening time $(P \leq 0.05)$ 
As mentioned above, the highest $L$ value was found in the control group cheeses, followed by cumin-added cheese and red pepper flaked -blended cheese, which are not statistically different. The lowest $L$ value was detected in cheese samples with thyme and isot pepper addition.

The value indicates redness and greenness and it varies between $0.36 \pm 0.45$ and $3.57 \pm 3.17$ for the cheese samples. The highest $a$ value during ripening was determined as 3.57 at 60 days, and the lowest as 2.35 at 15 days. The highest a value was determined as 8.02 in B4 while the lowest one was 0.36 in B2 samples. High values were detected in most of the red pepper flakes-added cheese samples, followed by isot pepper-added samples. The lowest a value, which is indicator of green colour, was found in minty cheese and it is significantly different from other cheeses. The high $b$ value is the indicator of yellow colour. B4 cheese had the maximum $b$ value and it was statistically different from other samples. The lowest $b$ values were recorded for samples B1, B3, B2 and CC that were not statistically different from each other.

Texture profile analysis (TPA) in white cheeses

There are seven texture parameters in the TPA, which are derived from the power-time curve. These are resilience, hardness, springiness, gumminess, cohesiveness, adhesiveness and chewiness. Hardness is the maximum force applied to the first compression of the cheese (Kim et al., 2004). Hardness is related to the proportion of salt within the cheese and water. If the salt content in the water is increased, the hardness increases (Kaya, 2002). The highest hardness value was $5.61 \pm 1.17 \mathrm{~kg}$ and the lowest was $3.10 \pm 0.69 \mathrm{~kg}$. As can be understood from the analysis of the dry matter, it is considered that the control group cheeses have lower hardness value than the spice-added cheese (Table 4). There was a prominent increase in hardness values on the $15^{\text {th }}$ day of ripening for all cheeses, especially for sample B2. This could be attributed to the increase in salt and dry matter concentrations in B2 cheese (Table 1).

The cohesiveness values increased on the $15^{\text {th }}$ day of ripening and then started decreasing. The highest values belong to isot pepper cheese (B5), followed by other cheese samples with no statistically significant difference (Table 4). The adhesiveness values of cheese samples were found to be $-14.75 \pm 11.33$ g.s.n and $-47.01 \pm 28.30$ g.s.n (Table 4). External tackiness values increased until the $30^{\text {th }}$ day of ripening and then decreased slightly. The highest external tackiness value was $-23.62 \pm 13.04$ g.s.n for thyme added cheese and the lowest value was $-42.79 \pm 20.03$ g.s.n.

Resilience is defined as the degree of restoration ability of foods during chewing (Truong et al., 2002). The values varied between $0.68 \pm 0.135$ $\mathrm{mm}$ and $0.76 \pm 0.09 \mathrm{~mm}$. In the study conducted by Karaman et al. (2012), it was determined that the elasticity-spreadability values of full-fat cheese produced from non-homogeneous creams were $0.56-0.73 \mathrm{~mm}$. The values we obtained in our research are close to the values of the investigator. The gumminess values ranged from $0.32 \pm 0.14$ $\mathrm{kg}$ to $2.23 \pm 0.45 \mathrm{~kg}$ with an overall average of $1.28 \pm 0.61 \mathrm{~kg}$. Mehenktaş and Metin (2007) determined the average value of gumminess as 1.29 $\mathrm{kg}$ in full fat white cheese samples which is similar to the results of this study. The gumminess value was highest in the thyme-added cheese but it is not statistically different from other spice-added cheese. However, the control cheese had a significantly different gumminess value compared to the spice added cheeses.

Chewiness is defined as the chewing force required making a food ready for swallowing (Raphaelides et al., 1995). The values varied between $0.24 \pm 0.10 \mathrm{~kg} . \mathrm{mm}$ and $1.71 \pm 0.28 \mathrm{~kg}$.mm. The mean chewiness values during the ripening period increased from $2^{\text {nd }}$ day $(0.35 \mathrm{~kg} \mathrm{~mm})$ to $15^{\text {th }}$ day $(1.31 \mathrm{~kg} \mathrm{~mm})$, then decreased at $90^{\text {th }}$ day. According to the results of multiple comparison tests of chewiness values of cheese varieties, the highest value $(1.09 \mathrm{~kg} \mathrm{~mm})$ was observed in the cheese with thyme and the lowest value $(0.62 \mathrm{~kg} \mathrm{~mm})$ was in the control group cheese. The springiness values varied between $0.07 \pm 0.01$ and $0.28 \pm 0.18$. In terms of ripening period, it is hard to say that there is a real alteration in the springiness values. The highest springiness was determined in the isot pepper cheese (0.14) while the lowest $(0.10)$ was the control, black cumin and mint- added cheeses. 
TABLE 4. Changes in texture profile values of cheese samples

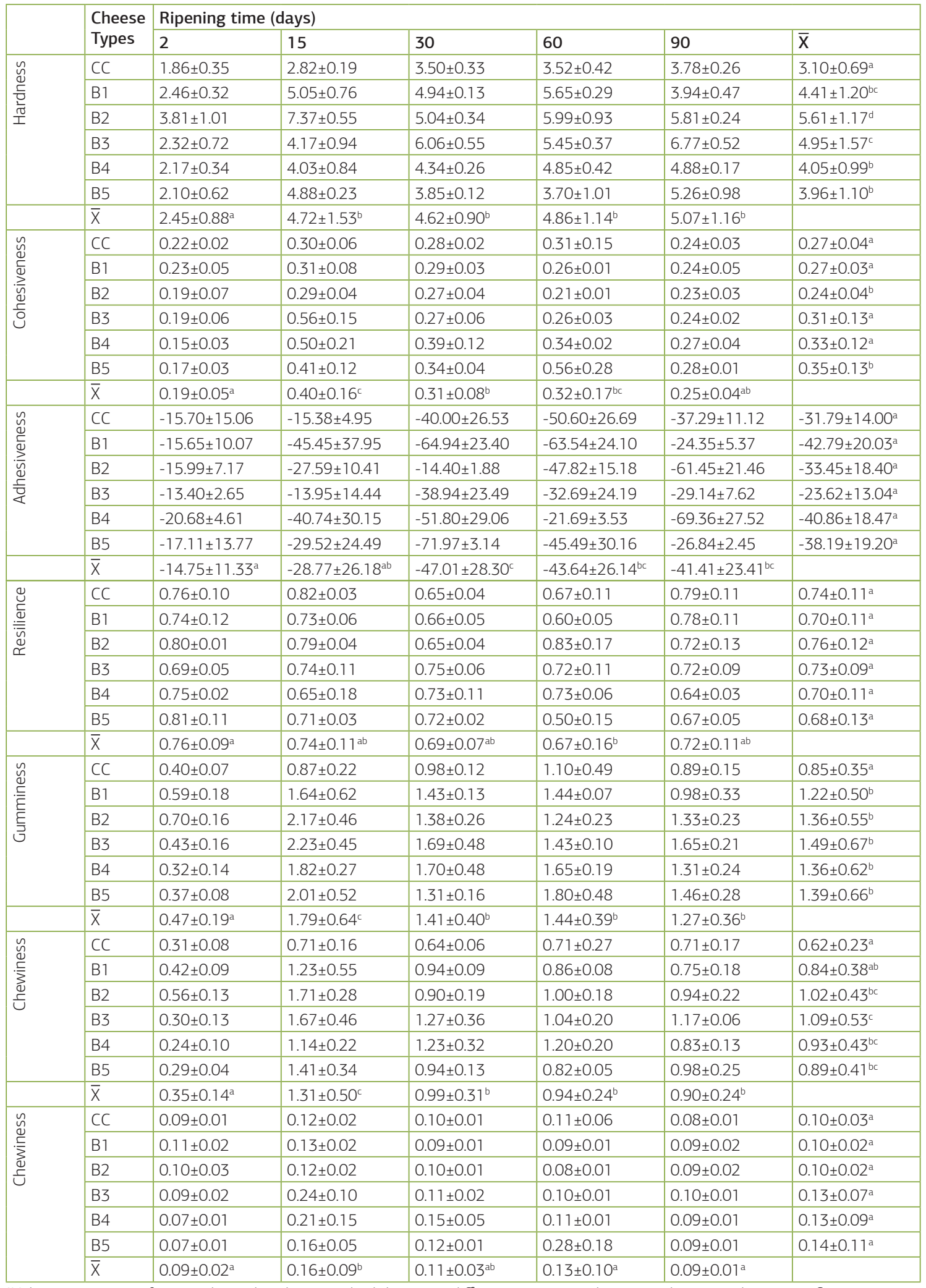

*Values are means of two replicated trials \pm standard deviation; different superscript lowercase letters indicate significant difference between cheese types and ripening time $(P \leq 0.05)$ 


\section{Sensory properties of white cheeses}

All sensory scores are presented in Table 5 . The control group (8.71) and black cumin added cheese samples (8.14) were the most preferred in terms of colour and appearance among fresh cheeses; while the lowest scores were determined in isot pepper (5.14) and red pepper-added cheese samples (5.71). Colour and appearance scores generally increased in cheese samples during the ripening period. The mean values also showed that control and black-cumin added cheeses were the most preferred ones regarding colour and appearance. The odour values varied between 6.14 and 9.44. Regarding the mean odour values, only isot pepper-added cheeses had significantly different odour value however, it was similar to those of red pepper and control. The structure and texture scores of the cheese samples changed between $6.71 \pm 1.16$ and $9.13 \pm 0.78$. Texture scores tended to increase as ripening proceeded; however, there is no significant difference found between mean textural scores of the cheese samples.

TABLE 5. Changes in sensory scores in White cheese during ripening period

\begin{tabular}{|c|c|c|c|c|c|c|c|}
\hline & \multirow{2}{*}{$\begin{array}{l}\text { Cheese } \\
\text { Types }\end{array}$} & \multicolumn{6}{|c|}{ Ripening time (days) } \\
\hline & & 2 & 15 & 30 & 60 & 90 & $\bar{x}$ \\
\hline \multirow{7}{*}{ 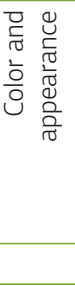 } & CC & $8.71 \pm 0.70$ & $8.75 \pm 0.97$ & $8.75 \pm 1.30$ & $8.38 \pm 1.32$ & $9.13 \pm 0.60$ & $8.74 \pm 1.06^{\mathrm{ab}}$ \\
\hline & B1 & $8.14 \pm 0.99$ & $9.00 \pm 1.41$ & $9.50 \pm 0.71$ & $8.75 \pm 0.66$ & $9.25 \pm 0.66$ & $8.95 \pm 1.04^{\mathrm{a}}$ \\
\hline & B2 & $6.71 \pm 1.39$ & $8.13 \pm 1.05$ & $7.88 \pm 1.17$ & $7.94 \pm 1.67$ & $8.69 \pm 1.34$ & $7.90 \pm 1.48^{\mathrm{bc}}$ \\
\hline & B3 & $7.29 \pm 0.88$ & $7.50 \pm 1.80$ & $8.56 \pm 1.16$ & $8.31 \pm 0.66$ & $7.88 \pm 1.76$ & $7.92 \pm 1.43^{\text {bc }}$ \\
\hline & B4 & $5.71 \pm 1.03$ & $8.25 \pm 0.83$ & $6.13 \pm 1.54$ & $7.00 \pm 2.06$ & $8.25 \pm 1.48$ & $7.10 \pm 1.79^{c d}$ \\
\hline & B5 & $5.14 \pm 1.12$ & $6.63 \pm 1.32$ & $7.38 \pm 1.11$ & $7.19 \pm 1.41$ & $8.00 \pm 1.41$ & $6.91 \pm 1.59^{d}$ \\
\hline & $\bar{x}$ & $6.95 \pm 1.63^{\mathrm{a}}$ & $8.04 \pm 1.50^{b}$ & $8.03 \pm 1.61^{b}$ & $7.93 \pm 1.53^{b}$ & $8.53 \pm 1.39^{b}$ & \\
\hline \multirow{7}{*}{$\begin{array}{l}\frac{1}{0} \\
\frac{0}{0}\end{array}$} & $\mathrm{CC}$ & $6.86 \pm 1.64$ & $8.13 \pm 1.05$ & $8.13 \pm 1.45$ & $8.38 \pm 1.11$ & $8.38 \pm 1.32$ & $8.00 \pm 1.43^{\mathrm{ab}}$ \\
\hline & B1 & $7.00 \pm 0.76$ & $8.00 \pm 1.22$ & $9.06 \pm 1.24$ & $8.63 \pm 0.70$ & $8.88 \pm 0.60$ & $8.35 \pm 1.19^{\mathrm{a}}$ \\
\hline & B2 & $6.86 \pm 1.36$ & $8.75 \pm 1.30$ & $8.88 \pm 0.93$ & $9.19 \pm 1.00$ & $8.56 \pm 0.68$ & $8.49 \pm 1.33^{a}$ \\
\hline & B3 & $7.29 \pm 1.75$ & $6.94 \pm 1.94$ & $9.44 \pm 0.68$ & $8.63 \pm 1.11$ & $8.75 \pm 0.83$ & $8.23 \pm 1.64^{a}$ \\
\hline & B4 & $7.86 \pm 0.64$ & $8.00 \pm 0.87$ & $7.38 \pm 1.49$ & $8.19 \pm 0.93$ & $7.31 \pm 1.64$ & $7.74 \pm 1.24^{\mathrm{ab}}$ \\
\hline & B5 & $6.14 \pm 0.99$ & $7.38 \pm 1.58$ & $7.63 \pm 1.32$ & $7.81 \pm 1.37$ & $7.13 \pm 1.17$ & $7.24 \pm 1.42^{b}$ \\
\hline & $\bar{x}$ & $7.00 \pm 1.36^{a}$ & $7.86 \pm 1.49^{b}$ & $8.42 \pm 1.44^{b}$ & $8.47 \pm 1.14^{b}$ & $8.17 \pm 1.30^{\mathrm{b}}$ & \\
\hline \multirow{7}{*}{ 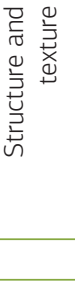 } & $\mathrm{CC}$ & $7.86 \pm 1.12$ & $8.75 \pm 1.09$ & $8.88 \pm 1.54$ & $7.94 \pm 1.18$ & $8.56 \pm 0.85$ & $8.41 \pm 1.25^{\mathrm{a}}$ \\
\hline & B1 & $8.00 \pm 1.20$ & $8.75 \pm 0.66$ & $9.13 \pm 0.78$ & $8.81 \pm 0.61$ & $8.88 \pm 0.78$ & $8.73 \pm 0.90^{a}$ \\
\hline & B2 & $7.00 \pm 1.41$ & $8.00 \pm 1.58$ & $8.50 \pm 1.32$ & $8.25 \pm 0.66$ & $8.50 \pm 1.35$ & $8.08 \pm 1.41^{a}$ \\
\hline & B3 & $7.43 \pm 0.90$ & $7.38 \pm 1.65$ & $8.75 \pm 1.20$ & $8.19 \pm 0.70$ & $8.38 \pm 0.86$ & $8.04 \pm 1.24^{a}$ \\
\hline & B4 & $6.71 \pm 1.16$ & $8.88 \pm 0.78$ & $8.00 \pm 1.41$ & $8.38 \pm 0.86$ & $8.31 \pm 1.03$ & $8.09 \pm 1.28^{\mathrm{a}}$ \\
\hline & B5 & $7.43 \pm 1.40$ & $7.88 \pm 1.76$ & $8.50 \pm 0.43$ & $8.50 \pm 1.12$ & $8.38 \pm 0.86$ & $8.15 \pm 1.27^{\mathrm{a}}$ \\
\hline & $\bar{x}$ & $7.40 \pm 1.29^{\mathrm{a}}$ & $8.27 \pm 1.44^{b}$ & $8.63 \pm 1.23^{b}$ & $8.34 \pm 0.93^{b}$ & $8.50 \pm 0.99^{b}$ & \\
\hline \multirow{7}{*}{ 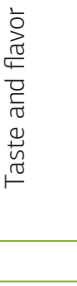 } & $C C$ & $7.43 \pm 1.29$ & $8.25 \pm 0.97$ & $8.50 \pm 1.32$ & $7.81 \pm 1.00$ & $7.81 \pm 1.06$ & $7.97 \pm 1.19^{a}$ \\
\hline & B1 & $7.00 \pm 1.31$ & $7.94 \pm 1.67$ & $8.44 \pm 1.04$ & $8.25 \pm 1.09$ & $8.75 \pm 0.83$ & $8.10 \pm 1.35^{a}$ \\
\hline & B2 & $6.29 \pm 1.67$ & $8.38 \pm 1.41$ & $8.88 \pm 0.93$ & $8.63 \pm 1.11$ & $8.88 \pm 0.05$ & $8.26 \pm 1.58^{a}$ \\
\hline & B3 & $7.00 \pm 1.31$ & $7.00 \pm 2.74$ & $9.56 \pm 0.77$ & $8.81 \pm 0.70$ & $8.25 \pm 1.20$ & $8.15 \pm 1.84^{\mathrm{a}}$ \\
\hline & B4 & $7.00 \pm 1.77$ & $8.44 \pm 1.45$ & $6.81 \pm 2.12$ & $7.38 \pm 1.80$ & $7.75 \pm 0.97$ & $7.49 \pm 1.76^{\mathrm{ab}}$ \\
\hline & B5 & $5.71 \pm 1.16$ & $6.19 \pm 2.42$ & $6.94 \pm 1.18$ & $7.06 \pm 1.94$ & $7.50 \pm 1.66$ & $6.71 \pm 1.86^{b}$ \\
\hline & $\bar{x}$ & $6.74 \pm 1.54^{\mathrm{a}}$ & $7.70 \pm 2.05^{b}$ & $8.19 \pm 1.64^{b}$ & $7.99 \pm 1.49^{b}$ & $8.16 \pm 1.28^{b}$ & \\
\hline \multirow{7}{*}{ 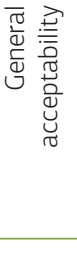 } & CC & $7.86 \pm 1.25$ & $8.38 \pm 0.70$ & $8.38 \pm 1.58$ & $8.19 \pm 1.06$ & $8.38 \pm 0.89$ & $8.24 \pm 1.15^{\mathrm{a}}$ \\
\hline & B1 & $7.00 \pm 1.31$ & $8.31 \pm 1.52$ & $8.69 \pm 0.83$ & $8.44 \pm 0.68$ & $8.75 \pm 0.71$ & $8.27 \pm 1.22^{\mathrm{a}}$ \\
\hline & B2 & $5.86 \pm 1.25$ & $8.38 \pm 1.41$ & $8.75 \pm 0.79$ & $8.56 \pm 0.68$ & $8.94 \pm 0.05$ & $8.15 \pm 1.54^{a}$ \\
\hline & B3 & $7.57 \pm 1.84$ & $7.06 \pm 2.65$ & $9.13 \pm 0.78$ & $8.69 \pm 0.75$ & $8.38 \pm 1.49$ & $8.18 \pm 1.82^{\mathrm{a}}$ \\
\hline & B4 & $7.14 \pm 1.55$ & $8.44 \pm 1.04$ & $6.75 \pm 2.09$ & $7.69 \pm 1.20$ & $8.25 \pm 1.17$ & $7.67 \pm 1.59^{\mathrm{ab}}$ \\
\hline & B5 & $6.14 \pm 1.12$ & $6.50 \pm 2.02$ & $7.19 \pm 1.27$ & $7.25 \pm 1.48$ & $7.88 \pm 1.45$ & $7.01 \pm 1.62^{b}$ \\
\hline & $\bar{x}$ & $6.93 \pm 1.58^{\mathrm{a}}$ & $7.84 \pm 1.85^{b}$ & $8.15 \pm 1.58^{b}$ & $8.14 \pm 1.14^{b}$ & $8.43 \pm 1.22^{b}$ & \\
\hline
\end{tabular}

*Values are means of two replicated trials \pm standard deviation; different superscript lowercase letters indicate significant difference between cheese types and ripening time $(P \leq 0.05)$ 
The scores were found to be similar to those reported by Tarakçı et al. (2005), except the black cumin added cheese.

The addition of spices to fresh cheeses was found to decrease the scores for taste and flavour (Table 5). It seems that taste and aroma becomes more preferred as ripening proceeds. The control cheese had the highest taste and aroma values (7.43) in fresh cheeses and the lowest value was found in isot pepper cheese (5.71). These values were in line with the research results of Tarakçı et al. (2006) on herbal cheeses. Based on the mean values, mint cheese was the most favourable among all smaples,while the least preferred one was the isot pepper cheese.

The overall acceptability scores ranged from $5.86 \pm 1.25$ to $9.13 \pm 0.78$. Among the fresh cheeses, the highest overall acceptability was found in the control group cheese (7.86) and the lowest in minty cheese (5.86). Among the matured cheeses, the highest value was thyme added cheese (8.94) and the lowest value was isot pepper added cheese (7.88). As in other sensory tests, general acceptability values have also increased during ripening.

\section{Conclusions}

This study showed that white cheese with spice addition is an alternative novel product with a good potential. Spice addition had positive effects on chemical, biochemical and sensory characteristics of White cheese. Cheeses with black cumin and isot pepper possessed higher ripening rates than others. Thereby, thyme, black cumin and isot pepper were found to be more effective on the $\beta$-casein fraction hydrolysis while thyme and isot pepper were better degraders for $a_{s 1}$-casein fraction. Except isot pepper added cheese, all tested spices contributed to the sensory properties of white cheeses. These new varieties of white cheese will present new choices for consumers looking for new tastes.

\section{Acknowledgement}

The present research was granted by the Scientific Research Project Coordination Unit of Ordu University (Ordu, Turkey) (Project No: TF-1423).

\section{Utjecaj dodatka različitih začina na kemijska, biokemijska, teksturalna i senzorska svojstva bijelih sireva tijekom zrenja}

\section{Sažetak}

Cilj ovog rada bio je ispitati utjecaj različitih začina na fizikalno-kemijska i senzorska svojstva sireva u salamuri. Šest različitih vrsa sira u salamuri proizvedeno je dodatkom 3 \% (w/v) začina poput crnog kima, mente, timijana, crvenog papra i crnog papra u mlijeko za podsiravanje. Svi sirevi su pakirani u vakuum i dozrijevali su pri $4 \pm 7^{\circ} \mathrm{C}$. Uzorcima su određivani ukupna suha tvar, udio masti, pH, titracijska kiselost, ukupni protein, indeks zrenja, udjel neproteinskih dušičnih tvari, udjel dušika u amino obliku, frakcije kazeina pomoću elektroforeze, senzorska i teksturalna svojstva. Naveden analize provođene su nakon 2, 15, 30, 60 i 90 dana skladištenja. Crni papar i crni kim utjecali su na povećanje stupnja proteolize bijelih sireva, i to prije svega na povećanje stupnja degradacije frakcije $\beta$-kazeina što je ukazivalo na intenzivinije zrenje kod ovih sireva. $\mathrm{S}$ druge strane, timijan i crni papar više su poticali hidrolizu $a_{s 1}$-kazeina. Osim crnog papra, svi ostali začini pozitivno su utjecali na senzorska svojstva bijelih sireva te povećavali njegovu prihvatljivost od strane potrošača. Rezultati ove studije potvrđuju kako dodatak začina pozitivno utječe na kemijska, biokemijska i senzorska svojstva bijelog sira, a tako obogaćeni sir predstavlja alternativni novi proizvod visokog potencijala.

\section{Ključne riječi: začin, bijeli sir, zrenje, tekstura}


1. Agboola, S.O., Radovanovic-Tesic, M. (2002): Influence of Australian native herbs on the maturation of vacuumpacked cheese. LWT-Food Science and Technology 35, 575-583. https://doi.org/10.1016/S0023-6438(02)90917-5

2. Akarca, G., Çağlar, A., Tomar, O. (2016): The effects spicing on quality of mozzarella cheese. Mljekarstvo 66, 112-121.

3. Akrami, F., Rodríguez-Lafuente, A., Bentayeb, K., Pezo, D., Ghalebi, S.R., Nerín, C. (2015): Antioxidant and antimicrobial active paper based on Zataria (Zataria multiflora) and two cumin cultivars (Cuminum cyminum). LWT - Food Science and Technology 60, 929-933. https://doi.org/10.1016/j.lwt.2014.09.051

4. Ayar, A., Akyüz, N. (2003): Effect of some herbs extract added at during the ripening of lipolysis of white cheese. GTD Journal28, 295-303.

5. Bütikofer, U., Rüegg, M., Ardö, Y. (1993): Determination of nitrogen fractions in cheese: Evaluation of a collaborative study. LWT-Food Science and Technology 26, 271-275. https://doi.org/10.1006/fstl.1993.1056

6. Case, R.A., Bradley, R.L., Williams, R.R. (1985): Chemical and Physical Methods. In Standard Methods for the Examination of Dairy Products, $15^{\text {th }}$ Ed.; Richardson, G.H., Ed., American Public Health Association: Baltimore, pp; 327-404.

7. Ceruti, R.J., Pirola, M.B., Ramos, E., Robert, L., Rubiolo, A.C., Sihufe, G.A. (2016): Use of an Exogenous Carboxypeptidase to Accelerate Proteolysis in Reggianito Cheese. Czech Journal of Food Sciences 34, 445-455. https://doi.org/10.17221/567/2015-CJFS

8. Çelik, Ö.F., Tarakçı, Z. (2017): The effects of starter cultures on chemical, biochemical and sensory properties of low-fat Tulum cheeses during ripening. International Journal of Dairy Technology 70, 583-591. https://doi.org/10.1111/1471-0307.12377

9. Cinbaş, T., Kiliç, M. (2006): Proteolysis and lipolysis in White cheese manufactured by two different production methods. International Journal of Food Science and Technology 41, 530-537. https://doi.org/10.1111/j.1365-2621.2005.01102.x

10. Coşkun, F. (2010): Antimicrobial activity of some spices and spice extracts used in foods. AcademicFood8, 41-46.

11. Creamer, L. (1991): Electrophoresis of cheese. BulletinInternational Dairy Federation 261, 14-28.

12. Dağdemir, E., Celik, S., Özdemir, S. (2003): The effects of some starter cultures on the properties of Turkish White cheese. International Journal of Dairy Technology 56, 215218. https://doi.org/10.1046/j.1471-0307.2003.00103.x

13. Dave, R.I., McMahon, D.J., Oberg, C.J., Broadbent, J.R. (2003): Influence of coagulant level on proteolysis and functionality of mozzarella cheeses made using direct acidification. Journal of Dairy Science 86,114-126. https://doi.org/10.3168/jds.S0022-0302(03)73590-5
14. Dimitreli, G., Exarhopoulos, S., Kleio, K., Antoniou, K.K., Zotos, A., Vasileios, A., Bampidis, V.A. (2017): Physicochemical, textural and sensory properties of white soft cheeses made from three different buffalo and cow milk mixtures. International Journal of Dairy Technology 70 , 459-610. https://doi.org/10.1111/1471-0307.12403

15. Everard, C., O'callaghan, D., Howard, T., O'donnell, C., Sheehan, E., Delahunty, C. (2006): Relationships between sensory and rheological measurements of texture in maturing commercial cheddar cheese over a range of moisture and $\mathrm{pH}$ at the point of manufacture. Journal of Texture Studies 37, 361-382. https://doi.org/10.1111/j.1745-4603.2006.00057.x

16. Fox, P.F. (1989): Proteolysis during cheese manufacture and ripening. Journal of Dairy Science 72, 1379-1400. https://doi.org/10.3168/jds.S0022-0302(89)79246-8

17. Fritsch, R.J., Martens, F., Belitz, H.D. (1992): Monitoring Cheddar cheese ripening by chemical indices of proteolysis 1. Determination of free glutamic acid, soluble nitrogen, and liberated amino groups. Zeitschriftfür Lebensmittel-Untersuchungund Forschung 194, 330-336. https://doi.org/10.1007/BF01193215

18. Goncu, A., Alpkent, Z. (2005): Sensory and chemical properties of white pickled cheese produced using kefir, yoghurt or a commercial cheese culture as a starter. International Dairy Journal 15, 771-776. https://doi.org/10.1016/j.idairyj.2004.10.008

19. Grappin, R., Rank, T., Olson, N. (1985): Primary proteolysis of cheese proteins during ripening. A review. Journal of Dairy Science 68,531-540. https://doi.org/10.3168/jds.S0022-0302(85)80855-9

20. Hannon, J., Wilkinson, M., Delahunty, C., Wallace, J., Morrissey, P., Beresford, T. (2003): Use of autolytic starter systems to accelerate the ripening of Cheddar cheese. International Dairy Journal 13, 313-323. https://doi.org/10.1016/S0958-6946(02)00178-4

21. Hayaloglu, A.A., Karabulut, I. (2013): Primary and secondary proteolysis in eleven Turkish cheese varieties. International Journal of Food Properties 16, 1663-1675. https://doi.org/10.1080/10942912.2011.604890

22. Hayaloglu, A.A., Guven, M., Fox, P.F., Hannon, J.A., McSweeney, P.L.H. (2004): Proteolysis in Turkish White brined cheese made with defined strains of Lactococcus. International Dairy Journal 14, 599-610. https://doi.org/10.1016/j.idairyj.2003.12.008

23. IDF (1986): Determination of fat content (SchmidBondzynski-Ratzlaff method) Cheese and processed cheese. Brussels, International Dairy Federation; Belgium.

24. Jha, S.N. (2010): Colour Measurements and Modeling. Chapter 2. Nondestructive Evaluation of Food Quality. Springer-Verlag Berlin Heidelberg.

25. Kamaly, K.M., Johnson, M.E., Marth, E.H. (1989): Characteristics of cheddar cheese made with mutant strains of lactic streptococci as adjunct sources of enzymes. Milchwissenschaft 44, 343-346. 
26. Kaminarides, S.E., Anifantakis, E.M., Alichanidis, E. (1990): Ripening changes in Kopanisti cheese. Journal of Dairy Research 57, 271-279. https://doi.org/10.1017/S0022029900026893

27. Karamana, A.D., Benlib, M., Akalın, A.S., Karaman, A.D. (2012): Microstructure of industrially produced reduced and low fat Turkish white cheese as influenced by the homogenization of cream. Grasas y aceites 63, 267-273. https://doi.org/10.3989/gya.106611

28. Kaya, S. (2002): Effect of salt on hardness and whiteness of Gaziantep cheese during short-term brining. Journal of Food Engineering 52,155-159. https://doi.org/10.1016/S0260-8774(01)00098-X

29. Kim, S.Y., Gunasekaran, S., Olson, N. (2004): Combined use of chymosin and protease from Cryphonectria parasitica for control of meltability and firmness of cheddar cheese. Journal of Dairy Science 87, 274-283. https://doi.org/10.3168/jds.S0022-0302(04)73166-5

30. McSweeney, P.L.H., Sousa, M.J. (2000): Biochemical pathways for the production of flavour compounds in cheeses during ripening: a review. Le lait 80, 293-324. https://doi.org/10.1051/lait:2000127

31. Mehenktaş, C., Metin, M. (2007): The Effects of using starter culture producing exopolysaccharide in reduced white cheese production, II. Effects on textural and sensory properties. Hasad Food 260, 16-25.

32. Nielsen S.S. (2003): Mohr Titration Food analysis laboratory manual, $3^{\text {rd }}$ ed., Kluwer Academic/Plenum Publishers; New York.

33. Peralta, C.N. (1986): Queso de pina: a new variety of fruit-flavored soft cheese from goat's milk. The Philippine Agriculturist 69, 15-23.

34. Raphaelides, S., Antoniou, K., Petridis, D. (1995): Texture evaluation of ultrafiltered Teleme cheese. Journal of Food Science 60, 1211-1215. https://doi.org/10.1111/j.1365-2621.1995.tb04558.x

35. Scolari, G., Vescovo, M., Sarra, P., Bottazzi, V. (1993): Proteolysis in cheese made with liposome-entrapped proteolytic enzymes. Le Lait 73, 281-292. https://doi.org/10.1051/lait:1993326

36. Singh, R., Shushni, A.M.F., Belkheir, A. (2015): Antibacterial and antioxidant activities of Menthe piperita $L$. Arabian Journal of Chemistry 8, 322-328. https://doi.org/10.1016/j.arabjc.2011.01.019

37. Soltani, M., Guzeler, N., Hayaloglu, A.A. (2015): The influence of salt concentration on the chemical, ripening and sensory characteristics of Iranian white cheese manufactured by UF-Treated milk. Journal of Dairy Research 82, 365-374. https://doi.org/10.1017/S0022029915000278

38. SPSS, (2000): Standard Version 12.0. SPSS for Windows, Release 120 0, Standard Version. Chicago, IL: SPSS Inc.

39. Taivosalo, A., Kriščiunaite, T., Seiman, A., Part, N., Stulova, I., Vilu, R. (2018): Comprehensive analysis of proteolysis during 8 months of ripening of high-cooked Old Saare cheese. Journal of Dairy Science 101, 944-967. https://doi.org/10.3168/jds.2017-12944

40. Tarakçı, Z., Coşkun, H., Tunçturk, Y. (2004): Some properties of fresh and ripened herby cheese, a traditional variety produced in Turkey. Food Technology and Biotechnology 42, 47-50.
41. Tarakçı, Z., Ekici, K., Sağdıç, O., Küçüköner, E. (2005): The effect of black cumin on ripening of Tulum cheese. Archiv Für Lebensmittel hygiene 56, 135-139.

42. Tarakçı, Z., Sağun, E., Durmaz, H. (2006): The effect of mendi (Chaerophyllum sp.) on ripening of vacuum-packed Herby cheese. International Journal of Dairy Technology 59, 35-39. https://doi.org/10.1111/j.1471-0307.2006.00239.x

43. Tarakçı, Z., Tunçtürk, Y. (2008): The effect of adjunct cultures on some chemical, biochemical properties of white-brined cheese. Journal of Food Biochemistry 32, 490-505. https://doi.org/10.1111/j.1745-4514.2008.00179.x

44. TGK (2013): Turkish food codec. Codex spices. Official newspaper; 10.04.2013 Official Gazette Number: 28614 , Codex No: 2013/12. Ankara, Turkey.

45. Topçu, A., Saldamli, I. (2006): Proteolytical, chemical, textural and sensorial changes during the ripening of Turkish white cheese made of pasteurized cows' milk. International Journal of Food Properties 9, 665-678. https://doi.org/10.1080/10942910500542238

46. Truong, V., Daubert, C., Drake, M., Baxter, S. (2002): Vanerheometry for textural characterization of Cheddar cheeses: Correlation with other instrumental and sensory measurements. LWT-Food Science and Technology 35, 305-314. https://doi.org/10.1006/fstl.2001.0872

47. Tunçtürk, Y., Ocak, E., Köse, Ş. (2014): Changes in chemical and physical properties and proteolysis of Van herby (otlu) cheese during ripening. Food Journal 39, 163-170

48. Üner, Y., Aksu, H., Ergün. Ö. (2000): Effects of spices of the various microorganisms, İstanbul University Journal of Veterinary Faculty 26, 1-10. 